\title{
Bees and Beekeeping from the Perspective of the Ontological Turn
}

\section{Monika Kropej Telban $\overline{ }$}

With a particular emphasis on the perspective of the human-animal relationship, the author presents forms of beekeeping as well as related narrative culture and painted beehive panels, which came into vogue in the second half of the $18^{\text {th }}$ century, decorating Slovenian apiaries. This practice was unique in Europe but was largely abandoned by the first decades of the $20^{\text {th }}$ century due to changing economic, social, and spiritual conditions. While apiculture and the industry involving bee products have become very profitable worldwide, in Slovenia beekeeping is also perceived as a true national symbol. Beekeeping has also found its place in larger cities, mainly on terraces and in parks. In contrast, however, the often harmful human intervention has also accidentally exterminated bees in many natural habitats. The author discusses the relationship between man and bees in the light of posthumanism, which has revolutionized the way scholars perceive non-human mental lives and abilities.

KEYWORDS: bees, folklore, narrative culture, ontological turn, posthumanism, beehive panels

\section{INTRODUCTION}

The human-animal relationship in the $21^{\text {st }}$ century has changed together with its related ontological premises. Researchers Graham Harvey (2006) and Colin Scott (2006) have called for "academic animism" or animist ontologies and a re-appraisal of the role of non-human agency and culture. Current theoretical movements in posthumanism (Wolfe 2010: 99-126) have discredited anthropocentric ontologies and emphasized that there exist other species with different ways of thinking about selves beyond the human (Kohn 2013: 94). Movements in ecocriticism have been making way for multispecies ontologies, and all this has changed the understanding of the habitat and cultural life on earth.

American anthropologist Tok Thompson has stressed that ontology has deep links with mythology, which is a branch of folklore, yet the discipline of folklore has likewise remained focused on the human, even while it is increasingly obvious that many of its core subjects are widely shared throughout the animal kingdom (Thompson 2019). Comparative mythological studies research folklore and narrative culture allows understanding associated worldviews through time and place, and in this sense also the changing 
relationship of human towards non-human animals. In this realm, bees have (and always have had) - in contrast to the majority of other animals - an unbelievably high position, which gives them a kind of divine character. Roman poet Publius Vergilius Maro (70 BC-19 AD) even considered bees a part of God's mind (Stanonik 2018: 22).

The origin of the collocation The bee does not perish but dies, which is still in use, is animistic in origin. According to France Bezlaj, thousands of years of Christianity could not take away the soul of the bee, as it did with all other animals (Bezlaj 2003: 1239). Because of this, and in contrast to the situation of other animals, neo-animism - presented by Philippe Descola (2013: 121-124), and advocated by modern anthropology - will not considerably change the position of the bees. Following this ontological concept of neo-animism, Viveiros de Castro in the sense of new animism stressed that human and non-human beings have the same culture and different natures, as reflected through this ontological turn (Viveiros de Castro 2003; after Telban 2017).

Bees are one of the rare species of insect that have been exploited by humans and moved closer to human dwellings. Because of the honey and wax produced by them, they have been perceived as prized animals, and soon their symbolic value found its way into the realms of the art and social culture of many nations. From their natural nests, created mainly in trees and hollow logs, they were moved to man-made artificial hives such as skeps and trunks, and finally to the beehives known as apiaries.

Among the insect world, the bee has been elevated to a high spiritual level and is perceived as a mediator between heaven and earth. According to ancient Slavic concepts of the World Tree, the bee is housed in the middle of the Tree's trunk and represents the integrator of the earth and celestial spheres. At the top of the World Tree nests a bird (eagle, hawk, or nightingale), and at its roots lies a dragon or a snake. Bees were ascribed royal symbolism as well as liturgical roles. In Eleusis and Ephesus, priestesses were named after bees, for example, Melissa. In ancient Greece, bees were consecrated to Silenus and mentioned in Homer's Iliad $(2,87)$. Honey was highly praised by Euripides, Ovid, and Virgil, and commended by the Bible.

Ignorant of biology, people even associated the bee with parthenogenesis (immaculate birth) and palingenesis (rebirth). The bee was depicted on graves as a symbol of the afterlife. It represents the human soul that, upon death, flies out of the deceased's mouth. The buzzing of bees was compared to the language of souls dwelling in the underworld (EM 2/1977: 305). Mead was perceived as the potion of immortality. According to the European emblematics of the $16^{\text {th }}$ and the $17^{\text {th }}$ centuries, the bee and beehives represent attributes of the personified golden age (EM 1977: 298).

In ancient Greece and Rome, sugar was not known; therefore, honey was the only substance to sweeten food. The Greek philosopher Plato, who was born in Athens, was called "the bee of Athens" since his speech was as liquid and sweet as honey; it was said that a swarm of bees had sat on his mouth when he was still in his crib. Similar characteristics were attributed to Xenophanes, Sophocles, Pindar, St. Isidore of Seville, St. John Chrysostom, and others. The association of the bee with speech was also common among the Hebrews. Their word for bee, Dbure, derives from the word $D b r$, which means speech, hence the link between the bee and the word (Keber 1996: 32). 
The bee is also associated, through words and speech, with the culture of language, rhetoric, poetry, and with diligence. Having lent its name to numerous Slovenian cultural and scientific institutions, the bee is a noble companion to culture in Slovenia as well as in other countries (more about this, see: Stanonik 2018: 60-86).

\section{BEE DWELLINGS AND THE PRODUCTION OF HONEY}

Through the dwelling perspective and the immersion of the organism-person in an environment of the lifeworld as an inescapable condition of existence (Ingold 2011: 153), the bees' lifeworld had rather prodigiously organized dwellings before man interfered and "domesticated" them.

Even in prehistory, people exploited bees, and collected honey by climbing trees and taking it from their nesting sites. The oldest representation of this activity can be found in eastern Spain in the vicinity of Bicorp, in the Araña Caves (Spider Caves). The painting shows two men hanging on a rope, gathering honey from a wild bee colony (Vodopivec/ Koloini, Švagelj 2016: 8). It is unknown when people stopped collecting honey from wild bees and started to domesticate them; indeed, this occurred in different parts of the world at different times.

For quite some time, zoologists did not know what kind of organization took place within the beehive or how bees reproduced and were equally ignorant of the fact that bees pollinate plants. As a result, different theories were formed. Historian Hesiodus described beehives, worker bees, and drones, and compared the latter to lazy women (Keber 1996: 21).

Occupants of the beehive are the queen bee, female worker bees, and drones. Contrary to the queen, which may live over four years, the life span of workers is short; they live only six weeks during the honey production season. The offspring survive winter. The drones that mate with the queen have no sting but are larger and bulkier than worker bees, and have a short rounded abdomen. While they live in the beehive during the summer, they are killed off by the workers later or else ejected from the hive in the autumn (Keber 1996: 34).

Wild bees nest in hollow trees and even in treetops, in rock cavities, and in tunnels in the ground. Like other animals, they live in their environment and have their own cultural patterns (Ingold 2011). Their homes are known for their strict organization. While very different from other animals' dwellings, such as the den, barn, badger's burrow, bird's nest and so on, the internal organization of bee nests bears some semblance to anthills (Keber 1996: 33).

Copying the structure of bee nests, humans have domesticated the bee and built hives from truncated hollow or hollowed-out tree trunks. In the Orient, where trees are scarce, hives were made from horizontally placed clay cylinders. In grain-producing regions, hives in the form of skeps were made from straw or wicker.

The Slavs were originally keeping bees in forests, in hollow trees called the brti. They probably knew about domestic beekeeping because the terms panj and $u l j$, both denoting a beehive, were widespread. They were also familiar with skeps, baskets made of wicker, which housed bees and were also known in Greece (Čebelarski muzej 1973: 6). Later, they started to construct horizontal beehives from split or hewn boards. They also 
produced differently-shaped baskets made of straw or willow wicker. Some hives were interwoven from clematis and coated with clay or cow dung. Beekeepers even used simple boxes covered with a wisp of straw tied together with vine or wicker. Basket hives were usually placed beneath gables or on some boards or racks away from the wind. Most of the still-preserved ones can be found in Pannonia.

Beekeeping has always been highly developed in Slovenia. Strabo (IV. 6) and Lucius Columella (IX) reported that Slovenian beekeepers exported wax and honey to Italy. Great contributions to Slovenian beekeeping were made by Peter Pavel Glavar (1721-1784); Anton Janša (1734-1773), the first teacher of beekeeping at the beekeeping school in Vienna; and Giovanni Antonio Scopoli (1723-1788), who was the first to write that the queen bee mates with drones in flight. In Slovenia, beekeepers have an association that was established in 1781, when they founded the Beekeepers' Brotherhood. The Beekeeping Association of Slovenia was founded in 1898.

In Slovenia, the most prevalent type of wooden beehive was named kranjič. Several such hives were placed in an apiary (the ulnjak), which was first attested in Slovenia in the $17^{\text {th }}$ century. Such apiaries were most common in the region of Gorenjsko/Upper Carniola. Apiculture was very well developed at the time, which is further corroborated by the Slovenian polymath Janez Vajkard Valvasor (1689), who reported on the extensive export of honey. Bees were also transferred in special baskets, or else in specially equipped wagons, to pastures of higher quality.

The kranjič was followed by the so-called Albert-Žnideršič hives and later replaced by the modern vertically stacked hives with removable boxes.

Over the centuries, beekeeping techniques, tools, and other beekeeping supplies evolved hand in hand with increasingly more complex hive designs. Until the $20^{\text {th }}$ century, the bee trade was quite vigorous with its many beekeeping fairs, among which those in Ig and in Kranj, where as many as up to three hundred hives were brought, were particularly well-known. The Slovenian domestic "Carniolan" bee (Apis mellifica v. carnica) is still cultivated in Slovenia. In the cross-border areas, the Italian (Apis mellifica v. ligustica) and the German (Apis mellifica v. mellifica) bees are also cultivated. The Carniolan bee is very adaptable to the climate and resistant to disease. It often produces new swarms, which is an essential trait in the constant battle for survival.

Beekeeping is becoming increasingly market-oriented, and bee products such as honey, pollen, royal jelly, propolis, beeswax, and even bee venom are used in nutrition as well as medicine (for more, see Adamič et al. 1984).

\section{PAINTED BEEHIVE PANELS}

The first painted beehive panel boards, unique in Europe, emerged in the second part of the $18^{\text {th }}$ century in Slovenia. Graphic templates were often used for this technique, which flourished particularly in the middle of the $19^{\text {th }}$ century. This method was used until the early $20^{\text {th }}$ century but was later abandoned due to the changed economic and social conditions as well as different lifestyles. (More about this: Makarovič \& Rogelj Škafar 2000: 22-27). 
The fact that Valvasor (1689) never mentioned painted beehive panels indicates that they were not yet in vogue in the $17^{\text {th }}$ century. According to Avgust Bukovec, it is very likely that older hives, which were the predecessors of the kranjič, bore simple signs such as the cross, the sun or the moon, spruce, and others. The authentic painted panels emerged towards the middle of the $18^{\text {th }}$ century, at the peak of the Baroque period. Dated 1758, the oldest known painted panel depicts the Virgin Mary with Infant Jesus.

Slovenian painted beehive panels generally measured $14 \mathrm{~cm}$ in height and were about $30 \mathrm{~cm}$ wide. The paintings were usually done in oil, and others some still in chalk. Although it is true that bees recognized their own hive by the painting on it the original reason for these panel boards was apotropaic. In addition, apiary owners wanted to emphasize the wealth of their farms and boast to their neighbours (Giesemann 2007: 145).

Painted beehive panels emerged almost spontaneously from people's consciousness and imagination, and swiftly spread wherever the traditional Slovenian wooden hive, the kranjič, was in use. The painting adorned the front panel above the entrance to the hive. These painted panels have several names, for example, the končnica, skončnica, and the čelnica in Carinthia, and the dovž in the dialect of Rovte. Inspiration came from folk narrative and folk song tradition, some also from paintings on glass and from graphic reproductions, which came to Slovenia from abroad.

The painting of Slovenian beehive panels enjoyed its golden age between 1820 and 1880. It was probably conceived in Gorenjsko/Upper Carniola, the area of Slovenia with the highest number of the painted panels that have been preserved to this day. The technique was soon copied in Austrian Carinthia, especially in Rož/Rosental and Podjuna/Jaunstein.

The painted kranjič hives can also be found in Germany, where they travelled together with the Carniolan bees from Slovenia. Similar painted panels were known in Pustertal in East Tyrol and in Lammertal in the region of Salzburg, Austria. They are distinguished from the Slovenian ones due to their larger format and different content, and most importantly were not a general expression of folk culture (Makarovič, Rogelj Škafar 2000: 26).

Slovenian painted panels started before the end of the $18^{\text {th }}$ century, and depict more than 700 different motifs. There are many biblical motifs from the Old and the New Testament (creation of the world, Judgement Day, Adam and Eve in paradise, Noah's ark, the lost son, the merciful Samaritan, etc.), folk narrative motifs, folk song and ballad motifs, and apocryphal legends (Legend of St. Genevieve ATU 383A, Receipt from Hell ATU 756C*, King Matthias, Pegam and Lambergar, The Devil Grinds a Woman's Tongue, Women's Mill, The Animals Bury the Hunter SNP 970, ATU*191* etc.), humorous and mocking themes, and motifs of the world turned upside down (the pig and the shoemakers, tailors fleeing the snail, the wind blows away the tailors, a woman drags her husband from the pub, animals dance with farmers, animals shave the hunter etc.), and historical themes (the French army, the Turks, two devils drive Luther and his wife Katra to hell, the farmer cradles the French soldier etc.). Further scenes of daily life, as well as farm chores. Beekeeping motifs were equally frequent (for instance the weighing of the beehive, the swarm capture). Depicted were also plants and animal motifs (the fox carries the chicken to her lair, the comedian with his bear, the camel and the elephant etc.). The panels also depicted exotic Oriental or Indian motifs, and many others. 
The narrative motifs depicted on the panels provide an insight into the conceptual world of the people, and particularly of beekeepers (more on the motifs, see: Makarovic 1989, Makarovič and Rogelj Škafar 2000; Cevc 1962, Kuret 1955, 1960, 1974, Jagodic 1955, Kumer 1957, Orel 1960, Giesemann 2005, 2007; Globočnik 2005, Gočež Kaučič 2018: 320-330).

Beehive panels also feature various saints, for example, St. Nicholas, the patron saint of sailors; St. Peter and St. Paul; St. Martin; St. Catherine, St. Barbara; and most frequently St. Hiob, who was considered the beekeeper of the bible. According to Gorazd Makarovič, such depictions of St. Hiob are the result of the replacement of wasps with bees; the former are featured in folk songs with Hiob-related motifs (Makarovič \& Rogelj Škafar 2000: 36). Hiob was considered the protector of beekeepers until the $19^{\text {th }}$ century, when he was replaced by St. Ambrose. St. Ambrose was an excellent speaker, and a legend has it that this was due to the fact that nectar (ambrosia) trickled from his mouth when he was a baby. Waxers and beekeepers selected him for their protector (Miklavčič, Dolenc 1973: 472; as cited in Stanonik 2018: 92).

Since beehive panels were so firmly ingrained in the Slovenian collective consciousness, we were not really aware of their uniqueness and importance for a long time. This was first pointed out by Michael Heinko (in 1840 in Carniolia Nos. 37, 38). In 1929, Stanko Vurnik wrote the first professional essay about the subject. The most comprehensive text until that period was written by Avgust Bukovec (in Slovenski čebelar 1934, 1942, and 1943), who also presented the panels' historical development, provided an analysis of the subject material depicted on them, and discussed some of the artists that painted them.

In the second half of the $20^{\text {th }}$ century, painted beehive front panels once again came into vogue. Traditionally painted beehive panels are modelled after the original design and sold as popular souvenirs.

\section{FOLK NARRATIVES ABOUT BEES}

Narrative tradition has preserved many folktales, riddles, proverbs, and folk beliefs about bees. Many aetiological legends speak about the creation of the bees. According to Egyptian tradition, the bee was born from the tears of the ancient sun god Ra that fell on the ground. In Christian legends, it was born from drops of Christ's sweat when he suffered on the cross, or from drops of his blood spilling from the wound inflicted by a peasant woman who had refused to give him his loaf of bread.

\section{When Did God Create Bees?}

Hanging on the cross between two thieves, the son of God suffered unbearable pain. In addition to other troubles and afflictions, he also became immensely thirsty. Then one of the soldiers brings a sponge soaked in vinegar to his mouth. The Redeemer takes several drops, but the bitter drink causes terrible pain to the suffering Son of God and elicits many droplets of sweat upon his cold forehead. 


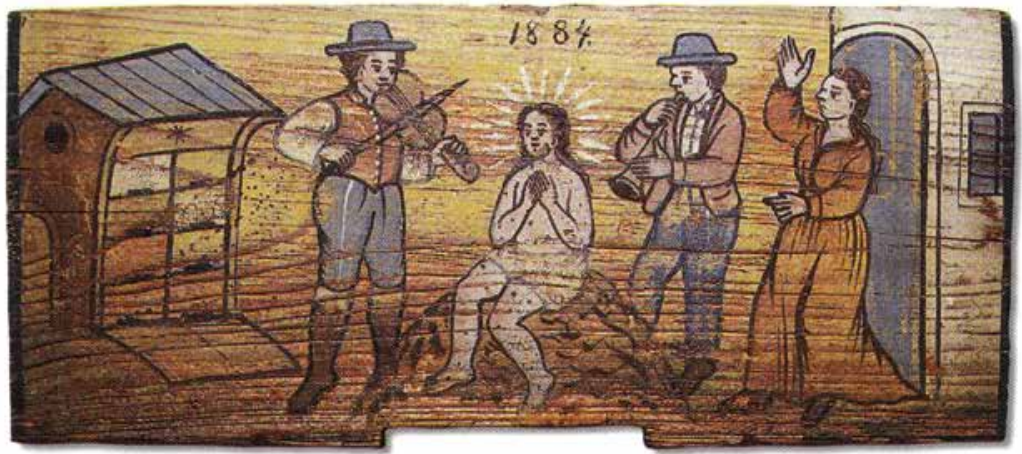

Fig. 1: Beehive panel depicting "Hiob on the dung", 1884. From the archive of Slovene Ethnographic Museum: no. 2357 (photo: Marko Habič).

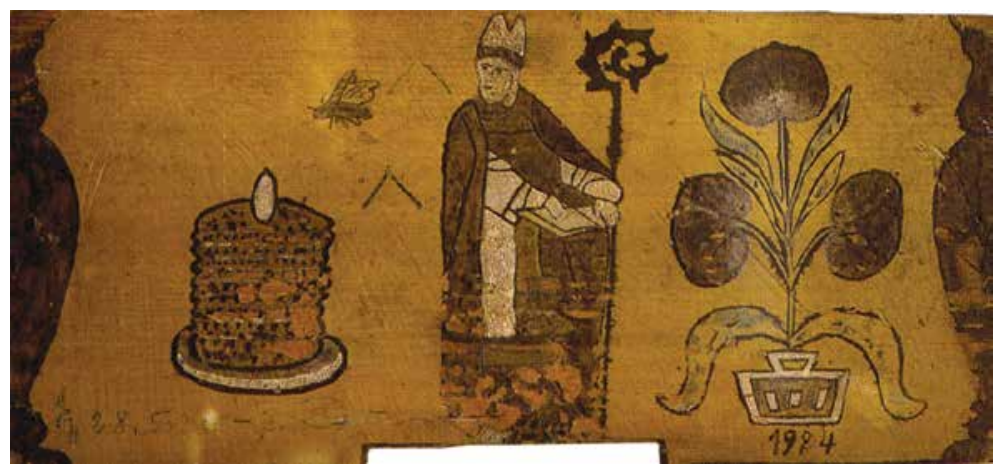

Fig. 2: Beehive panel depicting St. Ambrose, the patron saint of beekeepers and waxers (Kropej 1990: 49).

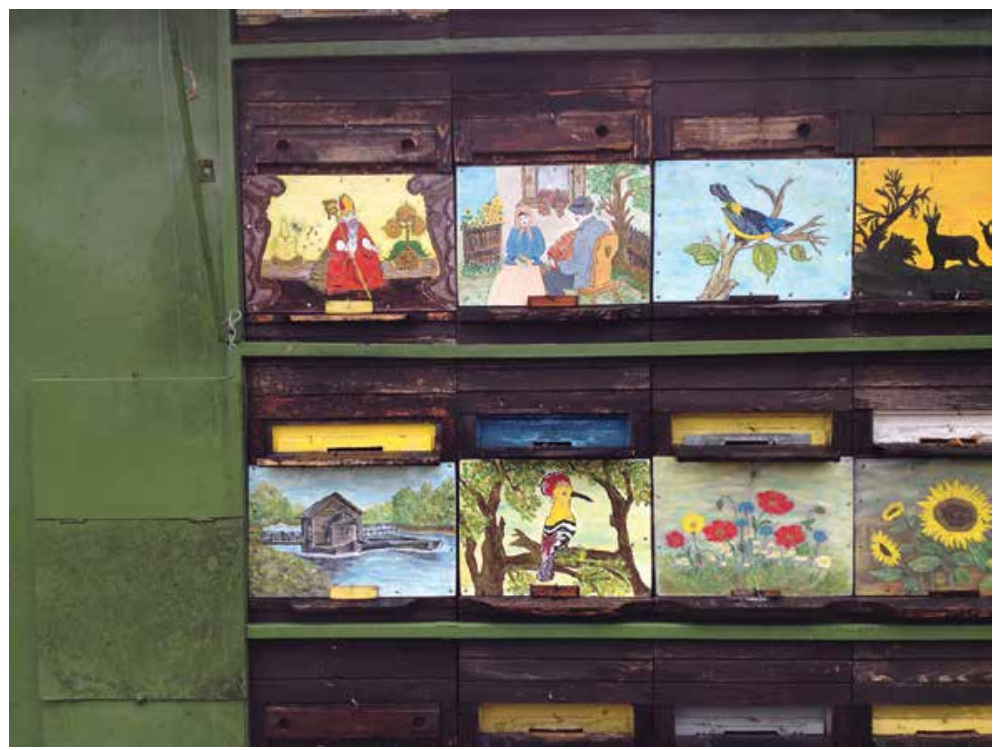

Fig. 3: Contemporary beehive panels from Petanjci in Prekmurje (photo: Kropej Telban 2017). 
In order to preserve the memory of this bitter hour, Christ asks - as legend would have it - his heavenly father to create from these droplets small animals that will diligently collect sweet liquid - honey. People are to imitate their hardworking efforts but also consume the sweet comb in order to forget any bitter hour in their daily lives.

The heavenly father fulfilled his son's wish and on the very same day created bees. For their living quarters, he chose hollow trunks as a reminder that Jesus breathed out his last breath and soul on a wooden cross.

This is why bees have always liked to dwell in hollow trunks. Later on, people started preparing special dwellings for the bees, namely baskets or beehives. Their favourite home is a hive made of woven wild vines. Why is that? Because vine stems strongly resemble the crown of thorns on the head of the suffering Christ as he died on the sacred wooden cross.

Because God has created the bee in memory of the bitter death of our Saviour, people do not say that bees "perish" as other animals do but "die" like the humans.

The honeycomb gives wax for candles that burn during every sacred service that reminds us of the bitter death of our Saviour. [Kosi 1896: 26-27: Kedaj je ustvaril Bog čebele?; Kosi 1897: 190-191; Stanonik 2018: 91].

\section{Christ and St. Peter (How Bees Came to Exist)}

While Christ and St. Peter roamed the world, they chanced upon a woman who was just putting loaves of bread in the oven. Christ says to her:

"Will one of them be mine?"

The woman has a generous nature. No beggar has ever left her house without a present, so she does not want to send Christ off with only empty words: "Let this one be yours," she says. She allots him the smallest one, which is on the peal at that moment. When she wants to put it in the oven, Christ says: "Wait, I have to mark it, so I do not take a different one once they are done." He comes closer and inserts his finger in it. The woman then puts the bread in the oven, and the two strangers settle in the shade to rest.

Christ's loaf rises visibly. Soon it is the largest of all. The woman finds this strange. She is sorry to have promised it to the traveller.

"Why," she thinks to herself, "it's not as if I had to give him exactly this one; it would be a pity because it has risen so much. Another one will do." She quickly makes another loaf, pokes her finger in it, and puts it in the oven. Once all the loaves are done, she calls the travellers and gives Jesus his loaf. He pauses, looks at the woman harshly, and says:

"Woman, this is not my loaf, give me the one you have promised!" The woman pretends ignorance, claiming that the loaf is the right one; he should take it. Since she can't persuade him, she gets angry and strikes Jesus in the temple. The Lord takes the proffered loaf, and he and Peter set off once again. After a while, Christ says to Peter: 
"Come look at my temple, where the woman has struck me."

Peter examines the temple and sees a wound, and there is a small worm in it. After a while, Jesus once again asks Peter to check his wound.

"It prickles and tickles a lot," Jesus says.

Peter looks at it and sees - what? A tiny animal, like a fly, that quickly flies to a nearby rock.

"Behold, Peter," the Lord says. This animal is a bee. It will produce wax, without which no mass will take place.

And so the bees came to existence. [Podgoriški, Kristus in sv. Peter. Slovenski glasnik 9/7 (July 1,1863): 213-214; Kosi 1890a: 30-31; Stanonik 2018: 90].

This legend is related to the legend ATU 751A "The Farmwife is Changed into a Woodpecker", but it is different because it explains how the bee has evolved from Christ's drop of blood. Allegedly, bees also originated from some drops of water that fell when Christ was baptized in the River Jordan (EM 1977: 299).

Russian and Ukrainian etiological legends about bees often speak about the rivalry between God and the Devil. In one of them, God was trying to create the bee, but the Devil changed it to the wasp. Later, God nevertheless managed to create the bee (Gura 1997: 449-450).

Some legends explain why bees have to die if they sting:

\section{Why Should a Bee Die After It Stings?}

St. Gall was so fond of bees that he stole the whole beehive from his neighbour. As he was carrying it on his shoulder, the bees started to sting him. At that time the bee needn't die after stinging. The saint got angry. "You've stung me - a holy man! From now on, every bee that stings me will have to die!" Since then, all bees die after stinging. But the bee never stings, unless it protects the honey or the brood. [Malenšek, Plamenicaroman o Primožu Trubarju 1957: 331 (Keber 1996: 23)]

Some of these folktales also refer to the negative side of bees, interpreting their sting as a means with which the bees originally wanted to kill other beings.

\section{Why Does the Bee Have to Die after Stinging?}

When God created the animals, the bee was one of them. Since the poor thing was so tiny, God wished to protect it by giving it the poisonous sting, saying: "Whomever you sting will have to die." The bee joyfully flew into the wide world that was still young. It acquired many, many sisters. Whenever they bore a grudge against someone, or when the sun was too hot for their little bodies, they would get angry and sting both people and animals, all of whom had to die. Since they kept stinging people, there were fewer and fewer people in the world. The angels in heaven cried because they had too much work. So the good Lord called a bee to him and said: 
"Bees are causing too much harm in the world, and for this, I shall punish you. Keep your stings and defend yourselves from the enemy. But from now on, every bee will have to die after stinging." The tiny bee bowed to God, spread its wings, and buzzed away to its sisters to tell them of the wrath of God.

In silent sorrow, the bees hung their heads, settled on an apple tree, and mourned... From that day, every bee must die after stinging. [Angelček 36/2 (October 1927/28): 23-24; Stanonik 2018: 91-92].

Theokritos (Eidyllion 19) describes how a bee once stung Cupid, who then complained to his mother, Venus. However, she reminded him that his arrows, although he was still very young, were just as painful as a bee sting.

The legend ATU 774K, St. Peter Stung by the Bees, narrates how Peter had rebuked Christ for punishing a sinner. Soon afterwards, Peter was stung by a bee. Now Christ rebuked Peter for having destroyed a bee nest and with it the entire colony. Bearing in mind the period in which it originated, this legend is unusually non-anthropocentric for it values the animal just as highly as the human. One of these legends was recorded in Terska dolina/Val Torre by Pavle Merku:

\section{The Legend of God, St. Peter, and the Bee (ATU 774K)}

God and St. Peter were walking from one country to another, speaking and teaching the Gospel. They arrived at Sodom and Gomorrah, where all sorts of things were taking place. God sent an arrow and destroyed everything. St. Peter says to him: "Why have you destroyed everything? There also lived those who believed in you. This was a bad thing to do!" "Oh, Peter, Peter" answers God, "what do you know? Let's proceed!" And they do. When they come to another country, God beholds a swarm of bees. "Peter, take this and put it on your chest!" Peter obeys him and puts the bees on his chest. They walk and walk, and then one of the bees stings Peter. And although it was the only one to do so, Peter crushes them all. [Terska dolina, Italija, Merku 1976: 357; Stanonik 2018: 90-91].

Since bees produce wax, which is also needed for candles that are lit at Mass, bees are perceived as divine animals. A medieval text claims that the nobility of the bee comes from the Garden of Eden but, because of the sin of people, bees were banished from there. God showed mercy upon them, and no Mass can be sung without wax since then.

\section{Why do Bees Celebrate Christmas Eve?}

The story tells us that on Christmas Eve, on the night that Jesus was born, bees are very cheerful. While they jump around and buzz, the queen bee sings, and you cannot get enough of her singing. Let us ask the bees, let us ask their queen why they are all so merry. The bees will answer thus: 
"When St. Joseph and Mary arrived in Bethlehem, they could not stay overnight in the city because all houses were filled with foreigners. So they left the town and stopped at a meagre stable in the field. At that moment, an old shepherd steps from the stable and urges them to stay there. Joseph and Mary enter, and the shepherd says to his wife:

"Attend to the strangers while I drive the sheep to pasture so there will be a little more room under our frugal roof. But before I go, I want to light up a wax candle so we can see one another." He lights the candle and leaves. In a little while, darkness falls and, during the night, Jesus is born. The holy Virgin Mary swaddles the baby Jesus and lays him in the manger. Joseph and Mary celebrate and venerate God for all his mercy and kindness. And because a wax candle illuminated the stable in which the holy baby Jesus was born, the bees also celebrate Christmas Eve and Christmas with great joy and delight. Not only last year and this year; the hardworking bees will glorify them until the end of the days, as long as the world shall exist. And rightly so, for wax candles are made of wax, which they collect from flowers with great effort and suffering. Bees worship God, our Father, for bestowing such honour upon them and illuminating the stable in which baby Jesus was born, with a wax candle. [Kobali 1884: 188; Kosi 1890b: 31-32; Kosi 1897: 192].

Some people believed that the bees sang on the eve of Christ's birth (Christmas Eve):

\section{How the Bees Sing at Midnight on Christmas Eve}

If you go to a spring at midnight, gaze into it, and see sheets and death, death will be visiting your house that year; but if you see a young woman, pretty as a bride, there will be a wedding. [...] In Livkovo, Matevž talked his family at midnight into going to see the bees and listen if they really sang. Of course, they were not singing; there was just some buzzing in the hive. [Podbrežnik Vukmir 2009: 266; Stanonik 2018: 92].

Slovenian legends explain how bees came to Carniola:

\section{How Bees Came to Carniola}

Noah, who had a sweet tooth, smuggled a beehive onto the ark. When the waters receded, the bees remained alone. After several generations of bees had grown up, the hive became too small. Their young queen bee, which was hatched during the flood, took three generations into a hollow palm tree. But the fourth time she was caught up in a storm and she, along with her family, was blown to Carniola. [Gnilšak 1989: 117; Stanonik 2018: 92].

Some historical folktales extol bees for helping to defeat the Turks by stinging them. One such example is the tale "The Bees Drive away the Turks" AaTh 1302*. 


\section{The Brave Cook}

In Šilentabor, in the region of Notranjska, there was a castle with strong walls and nine solid towers. On a beautiful day, the Turks suddenly appeared beneath the walls. They wanted to break through the fortified doors to the castle, which at the time was empty except for a female cook. This was a Sunday, so everybody else had gone to attend Mass at the nearby church. When the cook hears noises and banging, she goes to investigate. And what does she see? There are many Turks in front of the door, and they want to storm the castle. At first, she is too scared to do anything. But she soon gets an idea. Close to the walls is the castle apiary. She hastens there and throws every hive across the walls so that they break on the sturdy Turkish heads. The enraged bees start stinging the Turks. Stung by the bees, they beat a hasty retreat back to Bosnia. Thus, the cook saved the castle with her courage and common sense and was richly rewarded by the lord of the castle. [Ivan Marinčič, Hrabra kuharica, Izvir, list nižješolskega dijaštva v Marijanišču I/1, pp. 5-6 (not dated, around 1922), after: Stanonik 2018: 97].

Similarly, the bees allegedly drove the Turks away from Begunje as well:

\section{The Bees That Chased the Turks Away from Begunje}

A story is still told in Begunje above Cerknica that bees drove the terrible Turks away. Like many of them in that period, the local church was surrounded by a strong wall that formed a stronghold. As the Turks were approaching Begunje, the local population took whatever they could in haste, and fled to the stronghold. As beekeepers loved their bees even in those times and did not wish to leave them to the Turks, they took the hives with them. Little did they know that these bees would save them from certain death! When the Turks launch an attack near the church, the local men, both old and young, defend themselves like lions. But how can their courage and strength measure up to so many? They start to waver. Any moment the stronghold will be defeated, and woe to those who are in it! Then a beekeeper gets an idea. He strikes his head, saying: "Perhaps my bees can help and defeat the Turks? Just you wait, Turks!" He quickly gets a hive and throws it over the walls among the Turks. The hive naturally smashes, and the furious bees fall upon the Turks. In the resulting confusion they yell, they swear, they call to Allah, but nothing helps. The Christians throw down several more hives from all sides of the walls. There was a real slaughter! The blood did not run, but the Turks did run, with swollen heads, as fast as possible down towards Cerknica. Some of them were so swollen they could not see a thing. Well, of course, they were! Turks were no beekeepers, so the stings hurt them all the more. They have never returned to Begunje, stating: "We never want to go back to Begunje, their flies are too angry!" [Slovenski čebelar 1902, after Ovsec 1984: 49]. 
Several animal tales and fables praise the diligence of the tiny bees in contrast to the greediness and frivolity of the bumblebees (Bolhar 1975: 13-14); others explain how the bees started to collect honey for people while the drones continued to wander. (Bolhar 1975: 14-16).

Internationally spread is the fable about the bee and the dove "The Bee Falls into the Water" ATU 240A*, which narrates how the dove saves the bee that fell into the water. When a hunter wants to shoot the dove, the bee stings the hunter in his hand (Uther 2004: 151, Kropej Telban 2015: 382).

In the valley of Resia, a tale has been preserved about the Sheep and the Bee:

\section{The Sheep and the Bee}

The sheep and the bee constantly argued. So they went to court in Poltabja, and the bee was asked why they were arguing. It replied: "How could I not be angered - the sheep eats all the flowers, all the blades of grass, so I cannot gather anything, and I cannot make any wax. But there are so many churches, so many dead, and many candles are needed!" The sheep then replied: "What about me? They strip off my coat in the worst time of the year! While it is still freezing, I am without any coat, but still I have to keep silent!" [Recounted by Milka Santičeva, Oseaco/Osojane, recorded by Milko Matičetov on March 31, 1974].

Many animal tales speak about the Bear and the Bees, for instance, the tale "The Bear Climbs a Tree" ATU 88*. In this tale, the bear tries to reach the honey in the bee nest on a tree, so he climbs on a cart. When the cart suddenly moves, the bear falls to the ground (Uther 2004: 73, Kropej Telban 2015: 194-197). The following story also recounts the different ways in which the bear tries to reach the honey but always fails:

\section{The Bear Visits the Bees}

A beehive stood in the forest. The sweet smell of honey lured a sweettoothed bear out of the thicket. "I am bored," says the bear to the bees. "Let me be in your company for a while. I'll keep quiet and will not hurt you." The bees consent.

The bear crouches in front of the beehive, sadly hangs his heavy head on his front paws, and stealthily watches the hives. Sniffing, his mouth waters at the sight of the sweet meal.

Finally, when he can no longer resist, he slips quietly to the first hive and licks around the entrance.

Seeing this, a bee swiftly stings him in his tongue.

Roaring, the bear tears back to the forest. His tongue keeps swelling. Thinking that he is approaching his final hour, the bear sighs and groans:

"Oh, sweet death, oh, bitter death!"

But instead of dying, he recovers his health. 
One day, he is again tempted and beckoned by the sweet honey. He creeps quietly from the forest to the beehive and sniffs around the entrance to lick the sweet honey.

The bees have had enough. They fall upon his head and blind him with their stings.

In terrible pain, the bear runs back to the thicket. He is met by a fox.

"Who has poked out your eyes, my friend?" the fox asks.

"My sweet tooth!" moans the bear.

Aren't many of those who do not reflect upon the fact that passion without a bridle is a surefire trap similar to this unwise bear? [Kosi 1894: 98 - 99].

In the tales of magic, the bee is a magical assistant helping the fairy-tale hero achieve the desired goal. In tales and legends, it can also represent the human soul that emerges from the mouth of the dying or sleeping person, for example in some variants of the ATU 808A tale The Death of the Good and of the Bad Man.

A fantastic giant bee appears in humorous tales about lies, e.g., in The Great Bee and the Small Beehive ATU 1920G, which also tells how a large bee gets into a small beehive.

As can be seen from above, the bees have a special status in narrative tradition, and are in most Christian legends considered to be "God's creatures". They have preserved this role also in other tales, where they are usually presented as good protagonists.

Like in other places, and particularly in the era of the Enlightenment and in the Baroque period, many Slovenian priests included bees in their sermons. They extolled their diligence and set them as an example to people, for example, Janez Svetokriški and Father Rogerij Ljubljanski (Stanonik 2018: 98). People also recounted superstitions related to beekeeping. One of them tells of a beekeeper who placed the holy host into his beehive, which greatly increased the production of honey. However, he had to atone for this act (For more see: Makarovič \& Rogelj Škafar 2000: 35, Stanonik 2018: 94-98). The bees and their products were also incorporated in many medicinal practices and folk beliefs (For more see: Ovsec 1984, Adamič et al. 1984).

Many short folklore genres, like riddles, proverbs, and sayings about bees prove that in the $20^{\text {th }}$ century, bees were still greatly present in daily life. Here are some proverbs and sayings and riddles: "Which bird is sweet but cannot be eaten?"; "Do you know the bird that sweetens the dessert?"; "You will live like a bird in honey;" and "Busy as a bee" (For more see: Keber 1996: 21, Stanonik 2018: 102-109).

Literary creations frequently tell of the harmonious coexistence between the bees, beekeepers, and other people who take care of bees. Many beekeepers are certain that bees can detect when a person approaching them is angry or in a good mood (Tucak 2012: 1098), and that the bees also instil a sense of happiness and strengthen family ties (Vaitkevičius 2016: 87). 


\section{URBAN BEEKEEPING AND THE RELATIONSHIP BETWEEN HUMAN AND NON-HUMAN BEINGS}

Urban apiculture, the practice of keeping bee colonies in urban areas, especially on terraces and in parks, has recently become popular throughout Europe and in America. The Slovenian association of urban beekeepers Urban Beekeeper (Urbani čebelar) was founded in Ljubljana in 2014. The initiative had come from the municipality of Ljubljana at a time when the city was awarded the title of the Green Capital of Europe in 2016. The municipality also encouraged the beekeepers of Ljubljana to create the so-called Bee Path for which 110 linden trees will be planted over the next five years along the Path of Remembrance and Comradeship. There are many other bee-related events taking place in Ljubljana and elsewhere in Slovenia as well. Slovenia took the initiative to launch the European Honey Breakfast, which contains honey and is implemented under the name Slovenian Breakfast in kindergartens and elementary schools throughout Slovenia. An event named Honey Day is organized yearly along Stritarjeva Street in the very heart of Ljubljana. Among other popular events associated with the bee are Beekeeping Fairs that are also attended by beekeepers from a number of European countries.

Urban beekeeping is very well developed in Slovenia. In Ljubljana, beehives can be found on the roofs of the Cankarjev Dom cultural centre, the Španski Borci cultural centre, Park Hotel, and also the presidential palace; the latter is managed by the Urban Beekeeper Society. Some "urban beekeepers" attempt to initiate schoolchildren from nearby schools into beekeeping by organizing beekeeping clubs, and beekeeping societies organize lectures and other events for beekeepers and the general public.
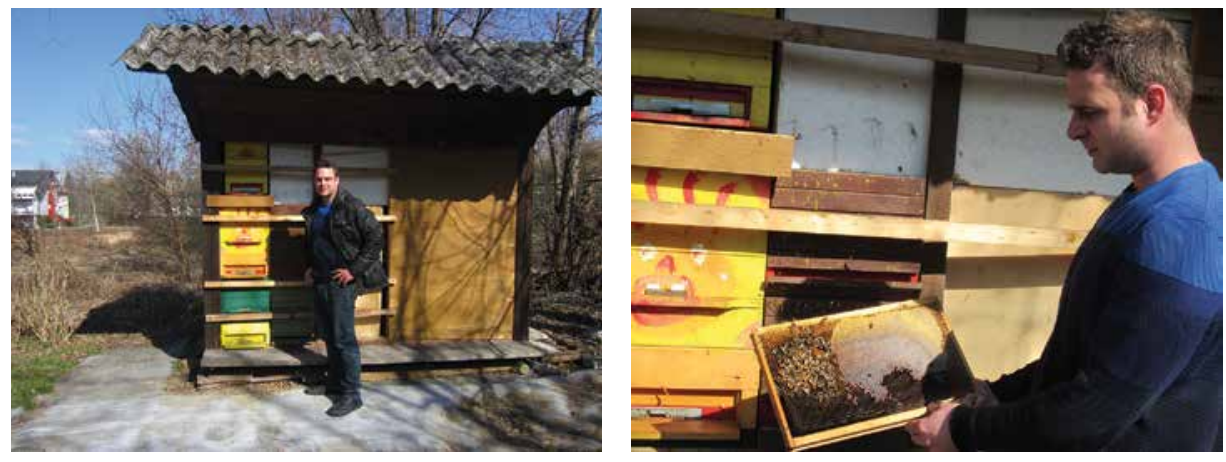

Fig. 4: Beekeeper Grega Benko' in front of his apiary in Ljubljana (photo: Kropej Telban 2017).

As part of the "Save the Bees" project, The Museum of Apiculture in Radovljica organized on September 22, 2016, a round table entitled "Cultural Heritage and Beekeeping" (Porenta 2016). Ljubljana Castle also hosted an exhibit that was opened on May 20, which is the birth date of the legendary Slovenian beekeeper Anton Janša. Slovenia has

\footnotetext{
1 I am indebted to Grega Benko for a great amount of information about beekeeping in Slovenia and about urban beekeeping in Ljubljana, and also for introducing to me the patterns of life of the bees.
} 


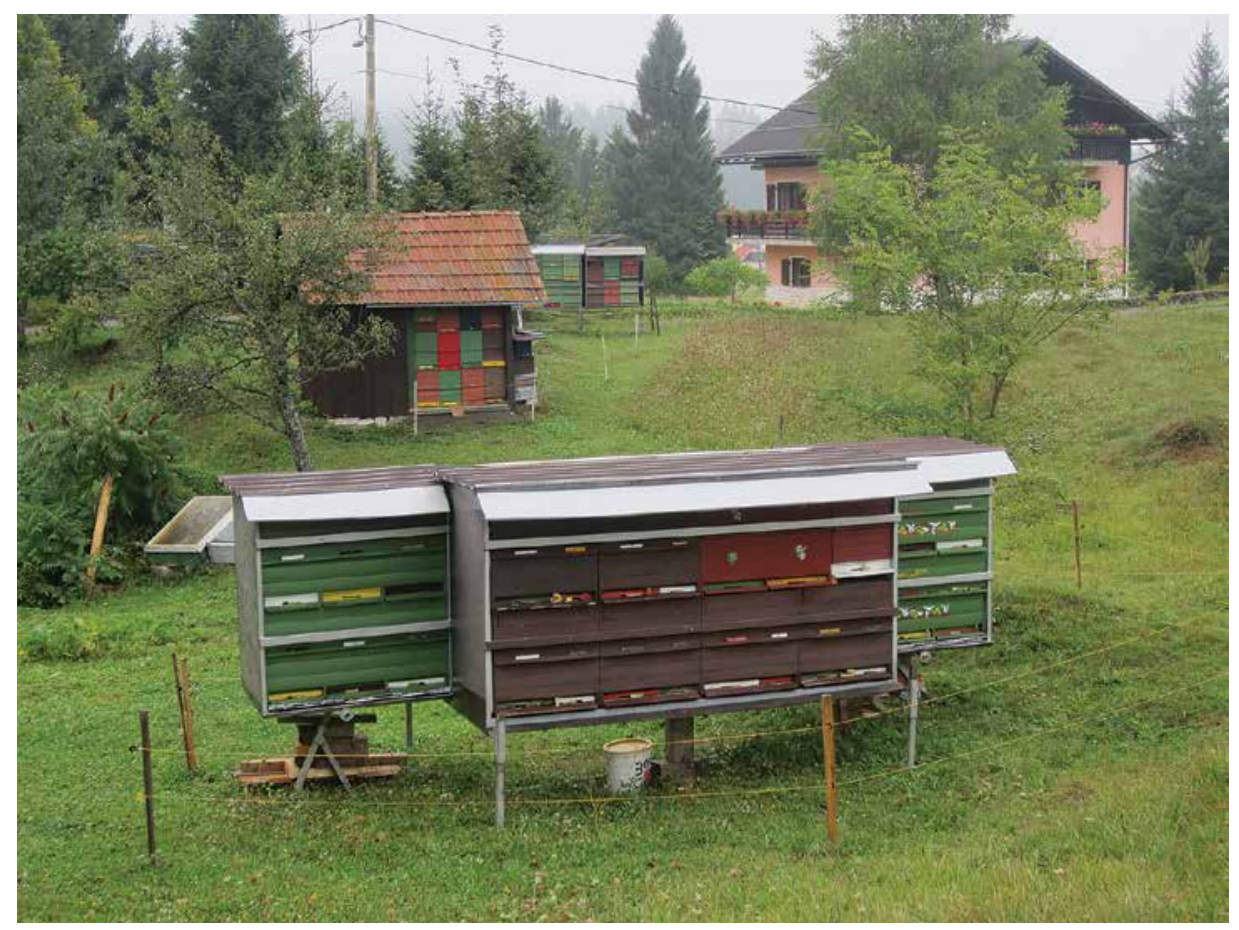

Fig. 5: Beekeepers’ Learning Path (Čebelarska učna pot) in Tršće in Croatia (photo: Kropej Telban 2017).

also proposed to the United Nations to declare May 20 the World Bee Day. In December 2018, the proposal was adopted within the framework of the UN Conference, and May 20 was officially declared the World Bee Day.

Many exhibitions, TV shows, international projects, learning paths, and other events with the intention to present bees and their lifeworld, have been organized in Europe in recent years. Beekeeping and the industry of bee products have become extremely popular worldwide. The production of and trade in bee products, which emphasize their apitherapeutic properties, are highly developed and profitable. At the same time, many beekeepers have stopped giving the bees sugar for food because this is bad for their health; and some beekeepers are practicing biodynamic beekeeping and biodynamic therapy. The foundations as Internationale Gabriele Stiftung (in Slovenia: Gabrielin sklad, Ajda Koroška) encourage a non-anthropocentric relationship towards animals, to sell only the honey which the bees have left over and do not use for themselves.

Apimondia, the International Federation of Beekeepers' Association, organized the First International Apicultural Congress as far back as 1897. Slovenia hosted the congress of 2003. The Beekeeping Association of Slovenia is applying to be the host of Apimondia again in 2021. In the words of its President Boštjan Noč, who is actively engaged in solving the problems of bees and beekeeping, beekeeping is not only about the acquisition of honey but much, much more - it is really a way of life. He stated: "Being a beekeeper is a Slovenian trait, for it is written in our genes. For the beekeeper, the bee is only partly an 
economic factor. Its greater value is in her usefulness to nature. One third of the world's food depends on bee pollination. Moreover, pollination is highly problematic in countries with plantation agriculture." (Glasilo Ljubljana 2018).

Yet it is not just the beekeeping activities and the extraction of bee products that make apiculture so very popular in Slovenia. This is essentially a special Slovenian culture, which is unique in the world. Bees represent a festive part of life. Working with them, the beekeeper becomes serene and suffused with joy, and is able to enjoy them far into his or her golden years. Many have developed an almost egalitarian relationship to the bee that is in accord with the non-anthropocentric way of thinking and understanding the world around us.

\section{CONCLUSION}

Since bees (and other animals as well) are extremely important for maintaining the ecological balance in the world, some people have in the $21^{\text {st }}$ century started to rethink their relationship to them from a perspective of posthumanism, which is broadening our understanding of culture and nature.

Beekeeping is expanded worldwide, and is very popular in many European countries, for example in Baltic societies, where family beekeeping is very much appreciated. In Lithuania, it was closely related to the notion of happiness and good fortune (Vaitkevičius 2016: 87), and mead used to play a significant social and political role in the life of nobility in the Grand Duchy of Lithuania (Vaitkevičiene 2016: 64). In Slovenia, the long-famed coexistence of the Slovenian beekeeper with the bees often focuses on the eco-centric understanding of nature and culture.

In contrast, human intervention in nature in many areas has had devastating consequences resulting in unintentional extermination of bees. Therefore, it is necessary that we improve our relation to the bees and our understanding of these extraordinary animals worldwide. Attitudes towards animals should be focused on cultural ecology and ethical awareness, and should also reflect the politics of animal breeding and exploitation. We can see that the shift from anthropocentrism towards ecocriticism, as Marjetka Golež Kaučič (2017: 40) defined it, has also influenced the ethical shift in apiculture.

Today, when the ontology is becoming increasingly oriented towards ecocriticism and non-anthropocentrism is making way for multispecies ethnography, the focus of our research is oriented towards the connection between the human and non-human, rather than merely on our species, or on a divide (Thompson 2019). The movements that we can observe in the contemporary societies and in changing sociohistorical epistemologies prove that the world is changing, and hopefully also the bees will be perceived as non-human beings with intrinsic value, without which there is no life on the earth. 


\section{REFERENCES}

Adamič, Andreja \& Vukmirović, Vera \& Koch, Verena 1984: Med in čebelji pridelki v zdravilstvu. In: Moč medu. Ljubljana, Koper: Založba Centralnega zavoda za napredek gospodinjstva, Lipa Koper, Kmečki glas, str. 90-117.

Bezlaj, France 2003: Zbrani jezikoslovni spisi II, edited by Metka Furlan. Ljubljana: Založba ZRC, ZRC SAZU.

Bolhar, Alojzij 1975: Slovenske basni in živalske pravljice. Ljubljana: Mladinska knjiga.

Cevc, Emilijan 1962: Fantastični ptici s panjskih končnic. Slovenski etnograf 15, str 119-134.

Čebelarski muzej v Radovljici 1973. Tekst so pripravili Emilijan Cevc, Stane Mihelič, Anton Polenec. Radovljica: Muzej radovljiške občine.

Čeh, Majda 1980: Čebelarstvo. In: Baš, Angelos (ed.), Slovensk ljudsko izročilo. Ljubljana: Cankarjeva založba, 66-69.

Descola, Philippe 2013: Beyond nature and culture. Chicago: Chicago University Press.

EM 1977: Enzyklopädie des Märchens. Handwörterbuch zur historischen und vergleichenden Erzählforschung. Begründet von K. Ranke. Ed.: R. W. Brednich et al. Berlin, New York: Walter de Gruyter, Vol. 2, 296-307: Kurt Ranke, Josef R. Klíma: Biene.

Giesemann, Gerhard, 2005: Panjske končnice. Ein slovenisches Phänomen unter die Lupe genommen. (Basler Studien zur Kulturgeschichte Osteuropas, Bd. 14, 657-676.

Giesemann, Gerhard, 2007. Panjske končnice. Slovenski fenomen pod drobnogledom. Traditiones $36 / 2,143-157$.

Globočnik, Damir 2005: Satirični motivi na panjskih končnicah. Etnolog 15, 345-365.

Gnilšak, Ida 1989: Običaji in verovanja v slovenskem čebelarstvu. In: Klaus Beitl (ed.), Človek in čebela: Apikultura na Slovenskem v gospodarstvu in ljudski umetnosti / Der Mensch und die Biene: Die Apikultur Sloweniens in der traditionellen Wirtschaft und Volkskunst. Ljubljana und Wien: Slovenski etnografski muzej und Österreichisches Museum für Volkskunde, str. 117-125.

Golež Kaučič, Marjetka 2017: Ontološki obrat v folkloristiki in/ali zoo/ekofolkloristika. Glasnik SED 57/3-4: 38-42.

Golež Kaučič, Marjetka 2018: Slovenska ljudska balada (Folkloristični zvezki 2). Ljubljana: Založba ZRC, ZRC SAZU.

Гура, Александр В. 1997: Симболика животных в славянской народной традиции. Москва: Индрик.

[Gura, Aleksandr V. 1997: Simbolika životnyh v slavjanskoj narodnoj tradicii. Moskva: Indrik.]

Harvey, Graham 2006: Animals, Animists and Academics. Zygon: Journal of Religion and Science $41 / 1,9-19$.

Ingold, Tim 2011: The Perception of the Environment. Essays on livelihood, dwelling and skill. London - New York: Routledge.

Jagodic, Marija 1955: Kmet ziblje Francoza. Slovenski etnograf 8, 153-170.

Kohn, Eduardo 2013: How Forests Think: Towards an Anthropology beyond the Human. Berkeley: University of California Press.

Kosi, Anton 1890a: Narodne legende za slovensko mladino 1. Ptuj: Samozaložba.

Kosi, Anton 1890b: Narodne legende za slovensko mladino 2. Ptuj: Samozaložba.

Kosi, Anton 1894: Zlate jagode. Zbirka basnij za slovensko mladino in preprosto ljudstvo. Ljubljana: Kleinmayr \& Bamberg. 
Kosi, Anton 1896: Zabavna knjižnica za slovensko mladino 5. Ljubljana: Samozaložba.

Kosi, Anton 1897: Sto narodnih legend. Slovenski mladini in preprostemu ljudstvu v pouk in zabavo. Ljubljana: J. Giontini.

Keber, Janez, 1996: Živali v prispodobah I. Celje: Mohorjeva družba.

Kobali, Pr. M. 1884: Zakaj čebele slave sveti večer. Vrtec 14/12 (1. 12. 1884), 188.

Kropej, Helmut 1990: Poslikane panjske končnice. Celovec: Mohorjeva založba.

Kropej Telban, Monika 2015: Tipni indeks slovenskih ljudskih pravljic. Živalske pravljice in basni. Ljubljana: Založba ZRC.

Kumer, Zmaga 1957: Godčevski in plesni motivi na panjskih končnicah. Slovenski etnograf 10, 157-166.

Kuret, Niko 1955: Babji mlin. Prispevek k motiviki slovenskih panjskih končnic. Slovenski etnograf 8, str. 171-206.

Kuret, Niko 1960: Babo žagajo. Slovenski etnograf 13,115-144.

Kuret, Niko 1974: Indijanci na naših panjskih končnicah. Traditiones 3, 196-197.

Miklavčič, Maks \& Dolenc, Jože 1973: Leto svetnikov III. Ljubljana: Zadruga katoliških duhovnikov.

Makarovič, Gorazd 1989: Slikarije na pročeljih čebeljih panjev. In: Klaus Beitl (ed.), Človek in čebela: Apikultura na Slovenskem v gospodarstvu in ljudski umetnosti / Der Mensch und die Biene: Die Apikultur Sloweniens in der traditionellen Wirtschaft und Volkskunst. Ljubljana und Wien: Slovenski etnografski muzej und Österreichisches Museum für Volkskunde, str. 53-115.

Makarovič, Gorazd in Rogelj-Škafar, Bojana 2000, Poslikane panjske končnice / Painted Beehive Panels. Ljubljana: Slovenski etnografski muzej.

Merku, Pavle 1976: Ljudsko izročilo Slovencev v Italiji zbrano v letih 1965-1974 / Le tradizioni popolari degli Sloveni in Italia raccolte negli anni 1965-1974. Trst: Editoriale stampa Triestina.

Orel, Boris 1960, Boj za hlače: Prispevek k motiviki slovenskih panjskih končnic. Slovenski etnograf 13, 145-168.

Ovsec, Damjan 1984: Čebele in čebelji pridelki v ljudskem izročilu. In: Moč medu. Ljubljana, Koper: Centralni zavod za napredek gospodinjstva, Lipa Koper, Kmečki glas, str. 45-69.

Podbrežnik Vukmir, Breda \& Kotnik, Irena 2009: Čuden prečudež: Folklorne in druge pripovedi iz Kamnika in okolice. (Glasovi 37). Celje: Mohorjeva družba.

Porenta, Tita 2016. Okrogla miza o kulturni dediščini v Čebelarskem muzeju. Glasnik SED 56/34, 156-157.

Scott, Colin 2006: Spirit and Practical Knowledge in the Person of the Bear among Wemindji Cree Hunters. Ethnos 71/1, 51-66.

Stanonik, Marija 2018: Čebela na cvetu in v svetu. Čebela v naravi in gospodarstvu, slovenski kulturni zgodovini, slovstveni folklori in literaturi. Ljubljana: Slovenska matica.

Telban, Borut 2017: Ontološki obrat v antropologiji deset let po izbruhu. Glasnik SED 57/3-4, 7-11.

Thompson, Tok 2019: Listening to the Elder Brothers: Animals, Agents, and Posthumanism in Native versus non-Native American Myths and Worldview. Folklore e. e. (in print).

Tucak, Zvonimir 2012: Čekajući roj: pčela - leteći liječnik i spasitelj prirode. In: Suzana Marjanić, Antonija Zaradija Kiš (eds.) Književna životinja. Kulturni bestiarij 2. Zagreb: Inštitut za etnologiju i folkloristiku.

Vaitkevičienè, Daiva 2016: Mead in the Baltic Society: From Beekeepers to Nobility. Tautosakos darbai 51. Vilnius, 32-65. 
Vaitkevičius, Vykintas 2016, From the Vocabulary of the Local Culture: Family Beekeeping. Tautosakos darbai 51. Vilnius, str. 66-87.

Valvasor, Johann Weichard, 1689: Die Ehre des Herzogthums Krain 1-4. Laibach-Nürnberg.

Viveiros de Castro, Eduardo 2003: And: After-dinner Speech Given at Anthropology and science, the $5^{\text {th }}$ Decennial Conference of the Association of Social Anthropologists of the UK and Commonwealth. (Manchester Papers in Social Anthropology, 7). Manchester: Manchester University Press.

Vodopivec, Janko / Koloini, Borut \& Švagelj, Jožef 2016: Čebelarski zapiski. Spremno besedilo napisala Borut Koloini in Jožef Švagelj. Nova Gorica: Goriški muzej.

Vurnik, Stanko, Slovenske panjske končnice. Etnolog 3, 1929.

Wolfe, Carty 2010: What is Posthumanism? (Posthumanities 8). Minneapolis - London: University of Minnesota Press.

\section{ČEBELE IN ČEBELARSTVO V LUČI ONTOLOŠKEGA OBRATA Monika Kropej Telban \\ $\infty$}

Čebele so zaradi medu in voska, ki ju proizvajajo, cenjene živali z bogato simbolno vlogo, prek katere so prišle tudi v umetnost in duhovno kulturo številnih narodov. Animističnega izvora je izraz, da Čebela ne pogine, ampak umre, ki je še vedno v rabi, kajti tisoč let krščanstva, kot ugotavlja France Bezlaj, čebelam ni moglo odvzeti duše kakor vsem ostalim živalim (Bezlaj 2003: 1239). Zaradi tega jim - za razliko od ostalih živali - neoanimizem, ki ga zagovarja sodobna antropologija (Harvey 2006, Descola 2013), v tem pogledu ne bo spremenil položaja.

Znamenitega grškega filozofa Platona, po rodu iz Aten, so imenovali atenska čebela, ker je govoril tako medeno tekoče, kot da bi se v zibki roj čebel usedel na njegova usta. Podobno se je govorilo o Ksenofontu, Sofokleju, Pindarju, sv. Janezu Zlatoustem, Izidorju iz Seville in sv. Ambrožu, ki je poleg Joba zavetnik čebelarjev. Tudi pri Hebrejcih je čebela povezana z govorom. Njeno ime Dbure izhaja iz besede $D b r$, ki pomeni govor, od tod tudi povezava med čebelo in besedo. Preko besede in govora je čebela povezana tudi z jezikom, kulturo, govorništvom in pesništvom, pa tudi z marljivostjo.

Čebelarstvo je bilo na Slovenskem že od nekdaj zelo razvito; Strabo (IV. 6) in Lucius Columella (IX) omenjata čebelarje na našem ozemlju, ki so v Italijo izvažali vosek in med. O gojenju čebel v klasičnih slovenskih lesenih panjih - kranjičih je leta 1689 pisal polihistor Janez Vajkard Valvasor. Na Slovenskem so tudi, kot unikum v Evropi, v drugi polovici 18. stoletja začeli poslikavati panjske končnice na kranjičih, katerih prednjo deščico nad žrelom so krasile. Poleg poimenovanj »končnica« najdemo še izraze »skončnica«, na Koroškem »čelnica«, v rovtarskem narečju »dovž«. Najstarejša danes znana končnica ima letnico 1758 in kaže podobo 
Marije z detetom. Poslikave so čebelam pomagale prepoznavati svoj panj, vendar so bili prvi vzroki zanje apotropeični. Z njimi so želeli tudi poudariti premožnost svoje kmetije in se postavljati pred drugimi. Poslikavanje panjskih končnic se je kmalu zaneslo tudi čez Karavanke na Koroško, kjer se je zakoreninilo v Rožu in Podjuni, poznajo ga tudi na Tirolskem.

Evidentiranih je preko 700 različnih motivov, ki so jih upodabljali na končnicah. Poleg nabožnih prizorov najdemo tudi motive iz ljudskega slovstva, zgodovinske motive, šaljive in posmehljive motive in prizore vsakdanjega življenja, živali in rastline, pa tudi eksotične, orientalske in indijanske motive. Navdihovali so se ob slikah na steklu ali pa ob motivih z grafičnih listov, ki so prihajali k nam iz tujine. Panjske končnice so začeli ponovno izdelovati v drugi polovici 20. stol.; tiste, ki nastajajo po starem vzoru, prodajajo kot spominke.

Čebele so pogosto omenjene v slovstveni folklori: o njih so se ohranili kratki folklorni žanri, kot so uganke, pregovori in reki, poleg tega pa tudi bogato pripovedno izročilo, predvsem veliko legend o njihovem nastanku. Rodile naj bi se iz kapelj Kristusovega potu, ko je trpel na križu; ali pa tudi iz njegovih ust; iz kapelj krvi, ki so pritekle Kristusu iz rane, ko ga je udarila kmetica, ki mu ni hotela dati njegovega hlebčka kruha. Nastale naj bi tudi iz kapelj vode, ki so ob Kristusovem krstu padale v reko Jordan. Ker čebele proizvajajo vosek, iz katerega delajo sveče, ki gorijo tudi v cerkvah pri maši, nastopajo v legendah kot božje živali: Bog je razširil svojo milost po čebelah in zaradi tega se maša ne sme brati brez voska.

Nekatere povedke o čebelah razlagajo njihov pik, saj naj bi prvotno hotele z njim pomoriti druga bitja. Teokrit (Eidyllion 19) pripoveduje, da je čebela nekoč pičila Amorja. Ko se je pritožil svoji materi, ga je Venera opomnila, da so tudi njegove puščice, čeprav je majhen, prav tako boleče kot čebelji pik. Legenda »Sv. Petra pičijo čebele« (ATU 774K) pa pripoveduje, kako je Peter očital Kristusu, ker je kaznoval grešnika, a mu je Kristus kmalu za tem oporekel njegovo dejanje, ko je zaradi pika ene čebele uničil celo gnezdo, ki ga je imel pod srajco (slovenski originali so v prilogi, gl. Appendix). Tako poslikave na končnicah kot pripovedi o čebelah so, času nastajanja primerno, tesno povezane s krščansko vero. Tudi pozneje so čebele ohranile vlogo »božjega bitja« in so bile v slovenskem pripovedništvu predstavljene kot poduhovljena bitja.

Čebelarstvo in industrija čebeljih proizvodov sta v zadnjem času v svetu doživela velik razmah. Čebele so začeli gojiti tudi v mestih, predvsem na terasah in $\mathrm{v}$ parkih, kjer se je $\mathrm{v}$ zadnjem času razmahnilo urbano čebelarstvo. V Sloveniji je bilo društvo Urbani čebelar ustanovljeno leta 2014, pobudnik zanj je bila Mestna občina Ljubljana $\mathrm{v}$ času, ko je bila Ljubljana imenovana za zeleno prestolnico Evrope v letu 2016. V tem času so nastale tudi številne čebelarske poti, v Ljubljani so ob Poti spominov in tovarištva so zasadili še več lipovih dreves in uvedli medeni zajtrk, iz katerega je nastal slovenski zajtrk. Zelo se je razvila proizvodnja čebeljih proizvodov, pri čemer se poudarjajo njihove apiterapevtske lastnosti.

Decembra 2018 je OZN na pobudo Slovenske čebelarske zveze razglasila 20. maj - rojstni dan Antona Janše, prvega učitelja čebelarstva na Dunaju - za svetovni 
dan čebel. Slovenski čebelarji ohranjajo svojo tradicionalno čebelarsko kulturo. Marsikdo med njimi je do čebel razvil skorajda egalitaren odnos; čebele torej $\mathrm{v}$ življenju slovenskih čebelarjev zavzemajo pomembno mesto.

Vendar pa je človek s svojimi uničujočimi posegi v naravo čebele na številnih območjih nehote iztrebil. Odnos do živali je zatorej treba usmerjati h kulturno-ekološki in etični ozaveščenosti tudi pri njihovem gojenju in izkoriščanju. Danes, ko je v času posthumanizma ontologija usmerjena vedno bolj ekološko in ko se antropocentrizem umika etnografiji različnih enakovrednih vrst - človeških in nečloveških subjektivitet (Golež Kaučič 2017), mora biti fokus usmerjen v povezavo in ne $\mathrm{v}$ razlikovanje med njimi. Razvoj, ki ga lahko opazimo v sodobnih družbah in v spreminjajoči se družbenozgodovinski epistemologiji, dokazuje, da se svet spreminja in da bodo tudi čebele razumljene kot človeku enakovredna bitja, ki imajo svoje kulturne vzorce in intrinzično vrednost in brez katerih ni življenja na zemlji.

\section{PRILOGA: SLOVENSKE LJUDSKE PRIPOVEDI O ČEBELAH}

\section{Kedaj Je ustVaril Bog ČEBele?}

Sin božji, viseč na križu med dvema razbojnikoma, trpel je neznosne bolečine. Poleg drugih težav in bridkostij, ki so ga obhajale, začelo ga je tudi neizmerno žejati. Tedaj mu pomoli jeden vojakov v kis (jesih) namočeno gobo k ustom. Zveličar vzame nekoliko kapljic, toda grenka pijača izvabi grozne muke trpečemu Sinu božjemu mnogo potnih kapljic na mrzlo njegovo čelo.

Da bi postavil spomin na prebridko uro, prosil je - kakor pripoveduje legenda-Kristus svojega nebeškega očeta, naj ustvari iz teh potnih kapljic živalice, ki bodo vzgledno marljivo nabirale sladko tekočino - med. Njihovo trudoljubnost naj bi ljudje posnemali, sladko strd pa uživali, da pozabijo vsako bridko uro, ki jih bode trla v vsdakdanjem življenju.

Oče nebeški je izpolnil željo svojemu božjemu Sinu in je ustvaril še isti dan čebele. Za stanovanje jim je odmeril drevesna dupla v znamenje, da je izdahnil Jezus na lesenem križu svojo dušo.

Zato čebele že od nekdaj kaj rade stanujejo v votlih deblih. Kasneje so začeli ljudje čebelam narejati posebna stanovanja - koše ali panje, in najljubši jim je baje panj, spleten iz divje vinske trte. Zakaj neki? Zato, ker so stebelca te rastline zelo podobna trnjevi kroni, katero je imel trpeči Kristus na glavi, ko je na lesu sv. križa umrl.

Ker je ustvaril Bog čebelo v spomin na pregrenko smrt božjega Odrešenika, zato ljudje o njej ne govore, da bi »poginila«, kakor druge živali, ampak čebela »umrje« kakor človek.

Iz njene strdi pa se pridobiva vosek za sveče, katere gorijo pri vsakem svetem opravilu, ki nas spominja na pregrenko smrt božjega Zveličarja. [Kosi 1896: 26-27: Kedaj je ustvaril Bog čebele?; Kosi 1897: 190-191; Stanonik 2018: 91]. 
2 Kristus in SV. Peter (Kako so BuČele postale?)

Ko sta Kristus in sv. Peter hodila po svetu, prišla sta k nekej ženi ravno, ko je vsajala pogačo. Bagovori jo kristus in upraša:

»Ali bo ktera pogača moja?«

Žena je bila dobrih rok: noben berač ni brez daru šel od hiše, in tudi njega ni hotela s samo besedo odpraviti:

»Naj bode pa ta-le tvoja«, pravi.

Odločila mu je najmanjo, ki je ravno imela jo na loparji. Hotela je vže vsaditi jo, kar povzame Kristus:

»Čaki, moram jo zaznamovati, da ne vzamem kake druge, kedar bodo pečene. Stopi bliže in vtakne prst vanjo. Žena jo zdaj dene v peč; nepoznana sv. moža pa gresta v senco počivat.

Jezusova pogača je vidno rastla. Kmalo je bila veča nego vse druge. Ženi se to čudno zdi. Pokesa se, ker jo je obljubila popotniku.

»E kaj, « reče sama sebi, »saj ni, da bi morala dati to, odpravim ga z drugo. Vendar le škoda je, ker je tako lepo visoka.«

Gre, naredi brž drugo, potakne prst vanjo, pa dene v peč.

Ko so bile vse pogače pečene, poklicala je popotnika, dala je Jezusu odmenjeno pogačo, pa on je obstal, ostro pogledal ženo in rekel:

»Žena, to ni moja pogača, daj mi obljubljeno.«

Žena se je nevedno delala, tiščala vanj in trdila, da je prava; naj jo le vzame. Pa ker ga ni mogla pregovoriti, zgrabila jo je naposled jeza in udarila je Jezusa po senci. Gospod je zdaj vzel pogačo, pa ne svoje, in šla sta s Petrom dalje. Čez nekaj časa je velel Kristus Petru:

»Pogledi, pogledi, kaj mi je tu na senci, kamor me je udarila žena. Peter je pogledal in videl rano, v rani pa črvička. Dalje grede reče Kristus drugič Petru, naj mu pogleda rane:

»Zelo me ščemi in ščegeče, « pravi.

Pogleda in kaj vidi? - Živalico, muhi podobno, ki je precej izletela na bližnjo skalo.

»Gledi Peter, « reče Gospod na to, »ta živalca je bučela; delala bo vosek, brez kterega se ne bo brala nobena sv. maša.«

In tako so postale bučele. [Podgoriški, Kristus in sv. Peter. Slovenski glasnik 9/7 (1. 7. 1863): 213-214; Kosi 1890a: 30-31; Stanonik 2018: 90].

\section{ZAKAJ MORAJO ČEBELE UMRETI, ČE PIČIJO}

Sv. Gal je imel rad čebele, pa jih je sosedu ukradel cel panj. Nesel jih je na rami, čebele pa vanj in so ga opikale! Takrat čebelam še ni bilo treba umreti, če so pikale. Pa se je svetnik razjezil in je rekel: »Mene, ki sem svetnik božji pikate? Katera me bo poslej še pičila, bo morala umreti!« Od takrat čebela umre, če piči. Pa nikoli ne piči, razen, če varuje med ali zalego. [M. Malenšek, Plamenica - roman o Primožu Trubarju 1957: 331 (Keber 1996: 23)] 


\section{ZAKAJ MORA ČEBELICA UMRETI, KADAR PIČI?}

Ko je Bog ustvaril živalce, je bila med njimi tudi čebelica. Ker je bila majhna - ubožica jo je hotel Bog zavarovati in ji je dal strupeno želo in rekel: »Kogar boš pičila, bo moral umreti.« Čebelica je vesela odbrenčala v široki mladi svet. Dobila je še mnogo sestric. In kadar se jim je kdo zameril ali da jim je solnce preveč grelo telesca, so jezno pikale ljudi in živali, in vsak človek je moral umreti.

Čebelice so pa naprej pikale ljudi, in ti so mrli in mrli in bilo jih je vedno manj. V nebesih pa so jokali angelci, ker so imeli preveč dela. In dobri Bog je poklical čebelico k sebi in ji rekel: »Prehudo delate, čebelice na zemlji. Zato vas bom kaznoval. Obdržite svoja žela in branite se z njimi pred sovražniki. A kadar bo katera pičila, bo morala umreti.«

Sklonila je drobna čebelica glavico pred Bogom, razpela krilca in odbrenčala pod božje solnce k svojim sestricam, da jim pove o božji jezi.

V tihi žalosti so sklonile čebelice glavice, sedle na jablan in žalovale... Od tistega dne pa mora vsaka čebelica umreti, kadar piči. [Angelček 36/2 (oktober 1927/28): 23-24; Stanonik 2018: 91-92].

\section{Legenda o Bogu sv. Petru in Čebelah (ATU 774K)}

Bog in sveti Peter sta hodila od ene dežele do druge in sta pripovedovala in učila evangelij. Prispela sta do Sodome in Gomore, kjer so počeli vse mogoče. Bog je vse uničil, poslal je strelo. In sveti Peter mu reče: »Zakaj ste vse uničili? Tam so bili tudi tisti, ki so verjeli v vas. Grdo ste storili!«

»Ah, Peter, Peter, « je rekel Bog, »kaj ti veš? Pojdimo naprej!«. In sta šla. Prišla sta v drugo deželo. Tu je Bog zagledal en roj čebel. »Peter, vzemi to in si deni na prsi!« Peter je ubogal Boga in si ga je dal na prsi. Hodila sta in hodila. Toda ena čebela je pičila Petra in on, čeprav ga je pičila ena sama, je zmečkal vse. [Terska dolina, Italija, Merku 1976: 357; Stanonik 2018: 90-91].

\section{ZAKAJ ČEBELE SLAVE SVETI VEČER?}

Pripovedka nam pripoveduje, da so čebela na badnjik (sveti večer) vso noč, ko se je porodil Jezus, navadno vesele. Skačejo in zujejo, a matica poje, da se je ne moreš dosti naslišati. Vprašajmo čebele, vprašajmo njihovo kraljico, zakaj so tako vesele, in čebele nam poreko takole:

»Ko sta sv. Jožef in Marija prišla v Betlehem, nista mogla v mestu nikjer prenočiti, ker so bile vse hiše prenapolnene tujih ljudi. Šla sta zatorej iz mesta ven na polje in našla ubožen hlev, pred katerim sta se ustavila. V isti čas stopi star pastir iz hleva ter ju nagovori, da naj pri njem ostaneta. Jožef in Marija stopita v hlev in pastir reče svojej ženi:

»Postrezi tujcema, a jaz poženem ovce na pašo, da bode nekoliko več prostora pod našo ubožno streho. Nu predno otidem, prižgati hočem še voščeno svečo, da se vidimo.«

Prižgavši svečo, otide. 
Za malo časa je bila temna noč in v tej noči je prišel Jezus na svet. Sveta devica Marija je povila dete Jezuščka v plenice in ga položila v jaslice. Jožef in Marija sta slavila in častila Boga za toliko milosti in dobrote.

In zato, ker je voščena sveča razsvetljevala hlev, v katerem se je porodilo sveto dete Jezušček, slave tudi čebele badnjik in božično noč z velikim veseljem in radostjo. A to ne samo lani in letos, nego slavile ga bodo do konca dni, dokler bode svet. In pravo imajo pridne bučelice, ker voščene sveče so od voska, katerega one nabirajo po cvetji z velikim trudom in trpljenjem. Čebelice časte Boga, našega očeta, ker jih je tako odlikoval, da je hlevec, v kaerem se je porodil Jezus, razsvetljevala voščena sveča. [Kobali 1884: 188; Kosi 1890b: 31-32; Kosi 1897: 192].

\section{KAKO NA SVETI VEČER ČEBELE POJEJO OPOLNOČI}

Opolnoči, kdor gre k studencu, pa da pogleda v studenec in vidi rjuhe in smrt, bo tisto leto smrt pri hiši; če pa vidi dekle, lepo kot nevesta, bo ohcet. /. . . Na Livkovem je Matevž pregovoril domače, da so šli opolnoči poslušat čebele, če res pojejo. Seveda pa niso nič pele, le malo je bilo v panju slišati brenčanja. [Podbrežnik Vukmir 2009: 266; Stanonik 2018: 92].

\section{KAKO JE ČEBELA PRIŠLA NA KRANJSKO}

Sladkosnedni Noe je v barko vtihotapil panj čebel. Ko so vode upadle, so čebele ostale same. Več rodov je zraslo in ker je domovanje postalo pretesno, je mlada matica, ki se je izlegla med potopom, odpeljala tri rodove v votlino palme. Četrtič jo je zalotil vihar in jo z družino vred zanesel na Kranjsko. [Gnilšak 1989: 117; Stanonik 2018: 92].

\section{Hrabra KUHARica (ATU 1302*)}

Na Šilentabru na Notranjskem je stal grad, ki je imel močno zidovje z devetimi trdnimi stolpi. Nekega lepega dne se nenadoma prikažejo Turki pod obzidjem in hočejo vlomiti skozi utrjena vrata v grad, kjer ni bilo razen kuharice žive duše doma. Ti so šli namreč, ker je bila nedelja, v bližnjo cerkev k službi Božji. Kuharica začuje šum in razbijanje ter gre pogledat, kdo je zunaj. In kaj vidi? Pred vrati je polno Turkov, ki hočejo vdreti v grad. V prvem strahu ne ve, kaj pošeti. Kmalu pa ji pride dobra misel v glavo. Blizu obzidja je grajski čebelnjak. Hitro gre do njega in pomeče vse panje čez obzidje, da se razbijejo na trdih turških buticah. Razkačene čebelice začnejo pikati Turke, ki vsi opikani hitro zbeže nazaj v Bosno. Tako je kuharica rešila grad s svojo hrabrostjo in razumnostjo, ter je bila od graščaka bogato obdarovana. [Ivan Marinčič, Hrabra kuharica, Izvir, list nižješolskega dijaštva v Marijanišču I/1, str. 5-6 (letnice ni, ok. 1922), po: Stanonik 2018: 97].

\section{0 Čebele, Ki so pregnale Turke iz Begunj (ATU 1302*)}

V Begunjah nad Cerknico je še sedaj razširjena govorica, da so čebele pognale grozovite Turke v beg. Tamošnja cerkev je bila v turških časih - kakor mnogo cerkva - obdana z 
močnim zidovjem, taborom. Ko so se bližali Turki Begunjam, skrili so se prebivalci za te utrdbe ter seboj vzeli, kar so v naglici vzeti mogli. Ker so čebelarji že takrat ljubili čebele in jih niso hoteli kar tako prepustiti Turkom, so jih vzeli s seboj v tabor. Niso si pa mislili, da jih bodo ravno čebele rešile gotove smrti. Turki napadajo tabor pri cerkvi. Možaki in mladeniči se branijo kot levi, a kaj pomaga njih hrabrost in moč proti tolikim! Jeli so omahovati. Zdaj pa zdaj bo tabor premagan in potem gorje onim, kateri so v njem! Nekemu čebelarju se pa nekaj zasveti v glavi, udari se po čelu in pravi: »Morda bodo pa moje čebele nam pomagale in Turke premagale? Čakajte Turčini, jaz vam bom dal popra!« Hitro skoči po panj čebel ter ga vrže čez zid med Turčine. Panj, seveda, se razbije, čebele postanejo zaradi padca ljute ter se zakade v Turčine. Med Turki nastane zmešnjava, kričijo, kolnejo, Alaha kličejo, a vse nič ne pomaga. Kristjani so vrgli še nekaj panjev med Turke in sicer na vseh straneh zidovja. No, to je bilo klanje! Kri sicer ni tekla, a tekli so Turki kar se je dalo tja doli proti Cerknici z oteklimi glavami. Nekateri niso nič videli, tako so bili otekli. Pa kaj ne bodo! Turki niso bili čebelarji, zato jim je pik tako škodoval. Nikdar več niso prišli potem v Begunje. Rekli so: »V Begunje ne gremo več, tam imajo hude muhe.« [Slovenski čebelar 1902, after Ovsec 1984: 49].

\section{BČELA IN GOLOBČIK (ATU 240A*)}

Bčela je bila padla v vodico; golobčik to viditi hitro s kljunom peresce od vejice odterga in ga v vodico spusti. Bčela peresce srečno doseže, se ga varno poprime in z njim iz vodice prigomazi; rešena je bila gotove smerti. Golobčik se zopet na drevo usede. Memo pride neki lovec, golobčika na drevesu zagledavši hitro s puško vanj pomeri in hoče sprožiti, pa - bčela pribrenči in pik! ga piči na roko. Lovec si roko mane, puška zmajana poči in vse zernje gre daleč od golobčika; golobčik zdrav in vesel z drevesa zleti. Kdo mu je življenje otel? -

Učite se, otroci! Od živalic hvaležnosti. [Anton Praprotnik, Bčela in golobčik. Šolski prijatel 3/2 (10.1.1854), str. 14]

\section{OvCA IN BEČELA}

Ovca in bečela sta se zmerom pričkali. Tedaj sta šli kar na sodnijo na Poltabjo. Tam gori so jih začeli spraševati - najprej bečelo - kaj imata, da se pričkata.

Bečela je rekla: »Kaj se ne bi jezila, ko mi sne vse rožice, vse travice, da ne morem nič ubrati, ne morem dajati voska, pa je toliko cerkva in toliko mertvih, bi bilo treba dosti sveč! «

Tedaj ovca je rekla: »Kaj pa meni, ki mi slečejo plašč v najhujšem letnem času! Ko je še velik mraz, sem brez plašča in moram molčati! « [Minka Santičeva po pripovedovanju Paske Vecíntave, Osojane, 31. 3. 1974. Zapisal Milko Matičetov.]

\section{MEDVED PRI BUČELAH (AD ATU88*)}

Tik gozda je stal bučelnjak. Prijetni duh strdi je izvabil iz gošče sladkosnednega medveda. »Dolgčas mi je, « prične kosmatinec čebelam, »pustite me nekoliko v svoji družbi; miren bodem in vam ne bodem storil ničesar.« - Bučele privolijo. 
Medved se spravi pod bučelnjak, dene žalosten težko svojo glavo na prednje šape ter skrivaj ogleduje panje, voha in sline se mu cedijo po sladki jedi.

Naposled, ko se ne more več upirati, splazi se tiho k prvemu panju ter liže okrog žrela.

To videč, piči ga neka bučelica hitro v jezik.

Medved zarjove ter zbeži kakor besen nazaj v gozd. Jezik pa mu čimdalje bolj oteka, in ker misli kosmatinec, da se mu bliža zadnja ura, vzdihne in stoka venomer:

»Oh sladka smrt, a bridka smrt!«

Toda umrl ni, ampak zopet ozdravel.

Nekga dne ga mika in zopet vabi sladka strd. Na tihem se priklati iz gozda k ulnjaku, približa se panju ter voha okrog žrela, da bi lizal sladko strd.

Bučelam pa je to dovolj. Zapraše se mu v glavo ter ga s svojim pikanjem oslepe.

S strašnimi bolečinami pobegne nazaj v goščo. Sreča ga strinja lisica.

»Prijatelj« Kaj pa ti je izteknilo oči? vpraša ga.

»Sladnost, sladnost!« stoka medved

Ali ni temu brezpametnemu medvedu podoben marsikdo, ki ne pomisli, da je brez uzde strast gotova past? [Kosi 1894: 98 - 99].

\section{HostiJa V ČEBELNJAKU}

Neki čebelar, ki s čebelarjenjem ni imel sreče, je prinesel v ulnjak hostijo, to pa mu je prineslo srečo in dobiček. Za to so zvedeli sosedje, šli so po duhovnika in v panju našli hostijo, okoli katere so čebele zgradile monštranco. Ta monštranca je bila upodobljena na končnici. [Makarovič, Rogelj Škafar 2000: 35; prim.: Stanonik 2018: 102 - 109].

Dr. Monika Kropej Telban, Scientific Research Centre of Slovenian Academy of Sciences and Arts, Institute of Slovenian Ethnology, Novi trg 2, SI-1000 Ljubljana, Slovenia, monika@zrc-sazu.si 